\title{
Uusi viestintäkoulutus iskee kirveensä kiveen
}

Suomi on edistyksellinen maa. Kun vielä runsaat kymmenen vuotta sitten pohdittiin kuumeisesti, voiko MTV:llä olla oma uutislähetys kansallisessa televisiossa, iloitaan nyt 1990-luvulla jo kulttuuriministerin suulla siitä, että viestintätùotteiden kysyntä lisääntyy.

Mutta älkää säikähtäkö. Kulttuuriministerin lausuma esitettiin yhteydessä, joka antaakin sille vallan päinvastaisen merkityksen. Anna-Liisa Kasurinen julkisti ajatuksensa tilaisuudessa, jossa hänelle luovutettiin viestintäkulttuurialan ammatillisen koulutuksen opetussuunnitelmaorganisaation mietintö.

Mietinnön taustalla kummittelee huoli siitä, että ulkomaisen tarjonnan lisääntyminen sähköisessä viestinnässä on uhka kansalliselle kulttuurillemme. Kasurisen toteamus voidaankin siis tulkita näin: koska viestintätuotteiden kysyntä lisääntyy, on meidän huolehdittava koulutusta lisäämällä siitä, että kansallinen kulttuurimme varjeltuu. Eli ei syytä huoleen. Suomi on edelleen Länsi-Euroopan brezhneviläisin maa.

Viestintäkulttuurialan (kauhea sana sinänsä) ammatillisen koulutuksen opetussuunnitelmaorganisaation esitys tähtää kiteytettynä siihen, että Suomeen syntyy kokonaan uusi ammattikunta - medianomit. Medianomeja olisi neljänlaisia sen mukaan, ovatko he erikoistuneet kuvan, valon vai äänen käyttöön viestintäalalla vai kenties tuotantotoimintaan. Erikseen on tehty vielä ehdotukset teatteri-ilmaisun opettajien koulutuksesta sekä jatkokoulutuksena annettavasta taideopettajien, video- ja elokuva-alan taideohjaajien ja teatteritekniikan koulutuksesta.

\section{Opetuksen haaskausta}

Mutta medianomit. Opetussuunnitelman saaneita ammattilaisia, jotka voisivat sijoittua televisio-, radio-, video-, elokuva- tai teatterialalle. Koulutustarve on varmasti oikein oivallettu. Sitä todistaa tietysti sekin, että mietinnön taustalla olevissa lausunnoissa oltiin varsin yksimielisiä koulutuksen lisäämistarpeesta.

Mutta opetussuunnitelma herättää joukon kysymyksiä. Koulutus aiotaan nimittäin järjestää alkuosaltaan siten kuin kaikilla muillakin keskiasteen peruslinjoilla eli valtioneuvoston vahvistamien oppimäärien mukaan.

Käytännössä tämä tarkoittaa melkoisia tuntimääriä mm. äidinkieltä, matematiikkaa, fysiikkaa, kemiaa, kansalaistietoa sekä liikuntaa ja terveystietoa. Sopii vain kysyä, mitä esimerkiksi liikunta ja terveystieto tekevät opetussuunnitelmassa, jolla pyritään tehostamaan, monipuolistamaan ja laajentamaan viestintäkulttuurialan koulutusta? Miksi opetustunteja ei käytetä niin, että kaikista medianomeista tulisi sekä kuvan, valon, äänen että tuotannon ammattilaisia? Yksityiskohtana voidaan kysyä vielä, miksi esimerkiksi tietotekniikkaa aiotaan opettaa vain ensimmäisen vuoden aikana, kun juuri tietotekniikka on ala, joka kehittyy huimaa vauhtia ja jonka sovellutuksilla on varmasti merkitystä viestinnän eri ammateissa?

Näiden kysymysten herääminen synnyttää vaikutelman siitä, että kaikkea ei ole mietitty aivan loppuun saakka. Mutta Suomi on ammattitutkintojen ja ylhäältä ohjatun suppealle alalle erikoistavan opiskelun luvattu maa. Kunnollisen koulutuksen pahimpana esteenä tuntuu alalla kuin alalla olevan se, että valtioneuvosto vahvistaa oppimääriä ja ainevalikoimia. Itse pääasia eli työelämän asettamat vaatimukset jäävät taka-alalle. Putkessa koulutettu opiskelija sopeutuu kieltämättä järjestelmään, mutta samalla hän varjelee kansallista kulttuuria niin tehokkaasti, että yhteiskunta ja sen toiminta luutuvat vain entisestään. Mutta Suomi onkin Euroopan kiinalaisin maa. 


\section{Liikkeelle liian myöhään}

Oman kritiikkinsä ansaitsee myös mietintöön sisältyvän ajattelun jälkijättöisyys. Mietintö perustuu nimittäin myös siihen, että viestintä ja taide ovat viime vuosina lähentyneet toisiaan. Medianomin tutkinnon yleistavoitteita jopa luonnehditaan toteamalla, että "'medianomilla on oltava taiteeseen ja kulttuuritajuun perustuva näkemys toiminnasta, jonka hän myös teknisesti hallitsee".

Samalla mikä-mikä-maa -linjalla on myös toteamus, jonka mukaan "'tutkinnon suorittaminen antaa perustan opiskelijan ammattiidentiteetin kehittymiselle ja jäsenyydelle ammattiyhteisössä sekä kyvyille arvostaa toisia ammattiryhmiä’.

Siis: jos ja kun viestinnän ja taiteen lähentymiseen on havahduttu vasta nyt, olemme il- man muuta myöhässä uudistaessamme viestintäkulttuurialan koulutusta. Tästä syystä: miksi uusi koulutus suunnitellaan jo vuosia vanhan keskiasteen uudistuksen pohjalle? Miksi ei uskalleta elää tulevaisuudessa? Miksi medianomeja ei kouluteta tämän vuosituhannen jälkeistä aikaa varten?

Viestinnästä tuli kaikkivoipa iskusana jo 1970-luvulla. Termi läpäisi julkishallinnon ja yritysmaailman yhtä nopeasti kuin ympäristönsuojelu. Samalla tekniikka on vienyt viestintää kymmenessä vuodessa pitemmälle kuin kukaan osasi kuvitellakaan. Mutta alan uutta koulutusta suunnitellaan vasta nyt. Hyvä tietysti näinkin. Mutta nyt pitäisi jo rohkeasti katsoa tulevaisuuteen ja suunnitella asiat uudelta pohjalta. Vai onko Suomi huomennakin hitaiden reaktioiden ja varman päälle pelaamisen maa?

MATTI LAITSAARI 